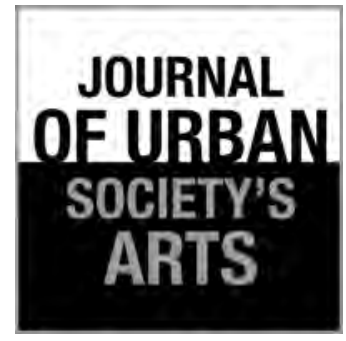

Volume 1 Nomor 1 , April 2014: 1-16

\title{
Ikonografi Karya Sudjojono "Di Depan Kelamboe Terboeka”
}

Zuliati

Bentara Budaya Yogyakarta

Jalan Suroto No. 2, Kotabaru, Yogyakarta

Tlp. (0274) 560404, E-mail: bentarabudayayk@gmail.com

\begin{abstract}
ABSTRAK
Tinjauan Ikonografi dalam Karya Sudjojono "Di Depan Kelamboe Terboeka". Penelitian ini mengupas lukisan "Di Balik Kelamboe Terboeka" karya Sudjojono secara ikonografi. Sebagai cabang ilmu sejarah seni, Ikonografi mempelajari makna dari sebuah karya seni melalui kajian aspek internal dan eksternal. Aspek internal sebuah karya seni seperti subject matter, gaya, dan aliran, sedangkan aspek eksternal berkaitan dengan situasi sosiohistoris yang melingkupi ketika karya seni tersebut dibuat. Maka dengan menggunakan pendekatan ikonografi akan diperoleh pemaknaan yang lebih luas dari sebuah karya seni. Berdasarkan penelitian dapat disimpulkan bahwa "Di Depan Kelamboe Terbuka" menggambarkan jiwa nasionalisme sebagai pemberontak estetika Mooi Indie yang telah mapan dalam kultur kolonial feodal. Karya tersebut menunjukkan pergulatan pemikiran dalam suatu situasi sosial yang didominasi konsep estetika tertentu. Sudjojono mampu merumuskan konsep seni yang berasal dari kejujuran dan kepekaan dalam melihat realitas sosial dan dikenal dengan kredo jiwa ketok.
\end{abstract}

Kata kunci: ikonografi, Sudjojono, Di Balik Kelamboe Terboeka, mooi indie

\begin{abstract}
The Iconographic Study of Sudjono's 'Di Depan Kelamboe Terboeka'. This study discusses the iconography of 'Di Depan Kelamboe Terboeka', a painting created by an influential painter in modern visual art of Indonesia, Sindudarsono Sudjono. Iconography as a branch of Art History learns the meaning of an artwork through the study of its internal and external aspects. The internal aspects include the items contained in an artwork such as a subject matter, style, and genre, whereas the external ones are related to the socio-historical situation in which the work of art is created. Iconography provides a broader understanding of a work of art. Based on this study, 'Di Depan Kelamboe Terboeka' is one of Sudjono's achievements depicting the spirit of nationalism as a rebel of the settle Mooi Indie aesthetics in the feudal-colonial culture. This painting reflects the creator's inner conflict in dealing with a certain social situation dominated by a particular aesthetical concept. Sudjono was successful in formulizing an art concept originated from his honesty and sensitiveness in witnessing the social reality known with a credo 'jiwa kethok'.
\end{abstract}

Keywords: iconography, Sodjojono, Di Balik Kelamboe Terboeka, mooi indie 


\section{Pendahuluan}

Sejarah seni rupa modern Indonesia sangat dipengaruhi oleh sosok Sindudarsono Sudjojono (selanjutnya ditulis Sudjojono). Ia lahir di Kisaran, Sumatera Utara pada tanggal 14 Desember 1913 (atau menurut sumber lain pada tahun 1912 dan 1917). Kota Kisaran pada masa itu merupakan salah satu kota kecil yang terletak di jalur raksasa perkebunan Pantai Timur Sumatera. Sudjojono lahir dari pasangan Sindudarmo dan Maridjem. Dia adalah satu-satunya anak dalam keluarga ini. Ayahnya bekerja sebagai kuli kontrak di perkebunan tembakau Deli. Sudjojono cukup beruntung bisa memperoleh kesempatan untuk belajar menggambar kepada seorang guru bernama Marsudi Judokusumo. Sudjojono melalui masa kecilnya di Kisaran. Selanjutnya dia dan keluarganya pindah ke Batavia. Ia menamatkan pendidikan dasarnya di Jakarta dan meneruskan pendidikan ke sekolah menengah pertama Teosofische Kweekschool di Gunung Sari, Lembang, Bandung (Siregar, 2010: 21-23).

Sudjojono merupakan tokoh penting dalam pergulatan pemikiran untuk mencari bentuk seni rupa yang mempunyai corak Indonesia. Seperti yang dikatakan oleh Sanento Yuliman (Siregar, 2010:36), Sudjojono adalah penggagas utama terciptanya revolusi baru seni lukis Indonesia. Revolusi itu dilakukan oleh Sudjojono pada kuartal terakhir dasawarsa 1930-an bersamaan dengan pencarian corak baru seni lukis Indonesia yang dihasratkan berbeda dengan corak sebelumnya.

Berkat ketajaman pikiran disertai keberanian mengartikulasikan gagasan-gagasannya dan rasa kebangsaan yang tinggi mendorong Sudjojono untuk terlibat aktif dalam pergerakan-pergerakan yang bersemangatkan nasionalisme khususnya di bidang kesenian. Ia merupakan tokoh penting dalam mendirikan Persagi (Persatuan Ahli Gambar Indonesia), turut mendirikan SIM (Seniman Indonesia Muda), juga pernah menjadi pembina seni lukis dalam seksi kebudayaan Poetera dan Keimin Bunka Shidoso pada zaman Jepang. Sudjojono bahkan disebut sebagai Bapak Seni Lukis Indonesia Baru oleh Trisno Sumardjo pada tahun 1949. Trisno Sumardjo dalam Majalah Mimbar Indonesia nomor 41-42 tahun 1949 antara lain menulis:

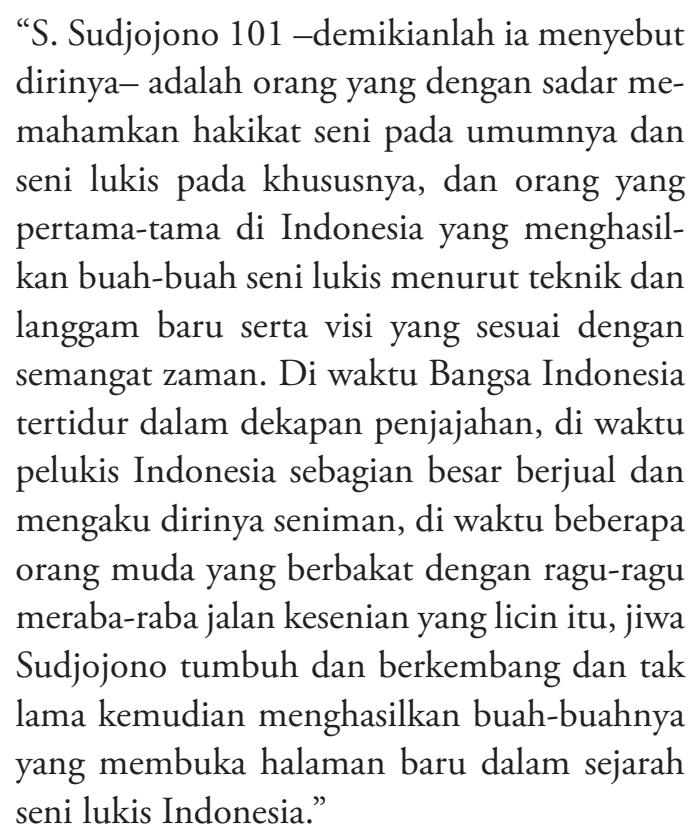

Bagaimanapun mengingat usia Sudjojono yang masih terhitung muda, pencapaian-pencapaiannya sangat berpengaruh dalam dunia seni rupa pada masa itu. Sejak akhir 1930-an hingga dekade 1950-an, kepeloporan Sudjojono dalam pengembangan seni lukis di tanah air memang sulit disangkal. Dia berhasil merumuskan suatu gagasan yang mengarahkan munculnya kesadarankesadaran baru, nilai-nilai, dan paradigma baru pula. Salah satu rumusan mengenai seni yang kemudian menjadi sebuah kredo yang populer di dunia seni rupa Indonesia sampai saat ini adalah “jiwa ketok" atau jiwa tampak.

Salah satu karyanya yang paralel dengan nilai-nilai estetik yang diperjuangkan dan termaktub dalam sebuah kredo "jiwa ketok" adalah Di Depan Kelamboe Terboeka ( selanjutnya ditulis DDKT). Karya ini dianggap sebagai salah satu karya penting Sudjojono dan menunjukkan satu gaya melukis baru di tengah zaman yang sedang memuja lukisan-lukisan bergaya romantik dengan menghadirkan sisi-sisi keindahan alam dan manusia Indonesia yang disebutnya sebagai lukisan Mooi Indie. Mengingat arti penting lukisan DDKT dan ketokohan Sudjojono dalam perkembangan seni lukis di Indonesia, penulis tertarik mengkaji lebih lanjut lukisan tersebut, terutama dari aspek keterkaitan dengan situasi zaman ketika lukisan tersebut dibuat dan terefleksikan dari lukisan terse- 
but. Untuk mendapatkan analisis yang lebih terarah, sistematis, dan tajam, penulis menggunakan pendekatan ikonografi.

Mengkaji karya seni rupa yang berasal dari masa lampau otomatis menggiring pada kesadaran ruang dan waktu. Untuk menyajikan cerita pada masa lalu dibutuhkan suatu konstruksi kesejarahan. Kajian sejarah seni rupa tidak saja membahas objek karya seni rupa sebagai artefak, tetapi juga faktafakta sosial dan mental masyarakat sehingga akan diperoleh suatu konstruksi pengetahuan mengenai sejarah yang lebih lengkap dan menyeluruh. Karya seni sebagai bagian dari kebudayaan juga mampu mengungkapkan jiwa zaman (zeitgeist). Dari pemahaman terhadap simbol-simbol yang terdapat dalam sebuah karya seni akan diperoleh sebuah gambaran dari penampang kebudayaan masyarakat pada suatu waktu. Untuk memperoleh gambaran yang menyeluruh tersebut dibutuhkan pembacaan dengan menggunakan berbagai pendekatan dan teori. Sebagaimana yang disampaikan sejarawan Agus Burhan (2003: 3) bahwa sejarah seni rupa merupakan konstruksi berbagai fakta yang menyangkut dunia seni rupa dalam perspektif waktu yang dipengaruhi oleh cara pandang, konsep, atau teori-teori yang dipergunakan.

Oleh karena itu, kajian sejarah seni rupa bersifat multidisipliner. Selain berurusan dengan berbagai dokumen dan fakta-fakta visual yang berkaitan dengan gaya, juga dibutuhkan pemahaman pada tema atau konsep serta makna intrinsik yang esensial. Salah satu pendekatan yang bisa digunakan dalam kajian sejarah adalah pendekatan ikonografi. Melalui pendekatan ini, karya seni akan menjadi perhatian utama dalam mengkaji sejarah seni, meskipun demikian juga dibutuhkan pemahaman pada aspek konstektual dan simbolik. Dengan demikian, dalam kajian ikonografi terdapat aspek diakronik, sinkronik, dan simbolik.

Kajian terhadap karya Sudjojono ini aspek diakroniknya berkaitan dengan sejarah seni lukis sebagai gerak dialektikal, ide, atau konsep kesenian berdasarkan perkembangan dari awal sampai akhir berdasarkan urutan waktu. Dalam prosesnya konsep atau ide baru muncul dari pergulatan pemikiran berdasar nilai-nilai lama yang telah ada dan diperjuangkan dalam medan seni untuk menghasilkan nilai baru. Sebagaimana munculnya Kelompok Persagi yang diusung oleh Sudjojono, berangkat dari penolakan terhadap nilai-nilai estetis masa-masa sebelumnya yang disebut dianggap tidak bisa mewakili ciri kebangsaan karena hanya menawarkan keindahan yang bersifat turistik.

Aspek sinkronik berkaitan dengan keterkaitan beragam fakta-fakta sosial, budaya, bahkan mental dari masyarakat suatu zaman ketika karya seni dihasilkan. Dalam hal ini karya Sudjojono DDKT akan menemukan konteksnya ketika dipahami melalui penelusuran sejarah sosiokultural pada masa tahun 1930-1940-an. Selanjutnya, melalui kajian ikonografi juga bisa diperoleh pemaknaan karya yang lebih dalam.

Ada tiga pertanyaan yang akan dijawab dalam penelitian ini, yaitu (1) bagaimana gaya karya DDKT; (2) bagaimana tema dan konsep lukisan DDKT; dan (3) bagaimana makna intrinsik lukisan DDKT.

Untuk memahami dan menganalisis maknamakna yang terkandung dalam lukisan DDKT diperlukan seperangkat pendekatan dan teori. Pendekatan dan teori utama yang akan dipakai adalah ikonografi yang dirumuskan oleh Erwin Panofsky. Ikonografi merupakan cabang dari sejarah seni yang berhubungan dengan pokok bahasan atau makna dari karya seni. Menurut Panofsky (1955: 26), untuk memperoleh makna dari suatu karya seni harus mengikuti tiga tahapan yang sifatnya prerequisite atau berurutan dan saling terkait satu sama lain. terdiri dari tahapan pre-ikonografi, analisis ikonografi, dan interpretasi ikonologi.

Tahap pertama disebut tahap praikonografi, yaitu tahapan untuk mengidentifikasi dan mendeskripsikan fenomena karya seni berdasarkan pada ciri-ciri visual yang tampak seperti: konfigurasi garis, warna, bentuk, teknik, dan material yang digunakan. Pada tahapan ini karya seni dideskripsikan secara faktual dan ekspresional. Makna faktual dipahami dengan cara mengidentifikasi bentuk yang tampak dalam objek karya seni. Makna ekspresional dipahami berdasarkan kejadian (events) yang terlihat di dalam karya berdasarkan pengalaman praktis (practical experience) dari pengamat. Deskripsi formalistik ini kemudian dikonfirmasikan menggunakan prinsip korektif 
pada sejarah gaya/style. Prinsip korektif pada tahap ini akan ditinjau pula karya Sudjojono sebelumnya yang berjudul Ibu (1935) dan Tjap Go Meh (1940) sebagai komparasi.

Untuk mendukung analisis pada tahap praikonografi ini diperlukan teori-teori seni sebagai teori pendukung, di antaranya teori yang berkenaan dengan struktur seni. Untuk mengkaji struktur seni dalam karya DDKT akan digunakan teori dari Edmund Burke Felmand dan Herbert Read. Menurut Feldman (1967: 222-278) struktur karya seni terdiri dari: (a) elemen-elemen seni rupa (garis, bentuk, tone/gelap-terang, dan warna), (b) pengorganisasian elemen seni (kesatuan, keseimbangan, ritme, dan proporsi), dan (c) kontribusi penikmat terhadap karya seni. Demikian juga yang dikatakan oleh Herbert Read dalam bukunya The Meaning of Art bahwa elemen karya seni rupa terdiri dari: garis, tone/gelap-terang, warna, bentuk, dan kesatuan. Pelacakan pseudo-formalistik pada tahap ini adalah sebagai syarat untuk memperoleh kepastian mengenai gaya lukisan tersebut.

Pemahaman mengenai gaya lukisan merupakan syarat yang tidak bisa dihindari dalam mempelajari sejarah seni rupa. Gaya lukisan akan memperlihatkan kecenderungan-kecenderungan ekspresi visual yang bisa dikelompokkan atau diklasifikasikan untuk menentukan gaya berdasar waktu, wilayah, teknik, subject matter, dan lain sebagainya. Dengan memperoleh pemahaman mengenai gaya lukisan akan membantu untuk membaca "hidden language" dari karya seni. Gaya lukisan dapat dideteksi melalui unsur-unsur seni rupa dan hubungan kualitatif antara elemen-elemennya. Gaya lukisan DDKT akan dianalisis menggunakan teori dari Feldman (1967: 138-204) yang membagi gaya menjadi empat yaitu: (1) gaya ketepatan objektif (objective accurancy), yaitu kecenderungan karya seni yang merujuk pada fenomena alam; (2) gaya susunan formal (formal order), yaitu karya seni yang diciptakan melalui aplikasi pola ukuran yang metodik untuk mencapai keseimbangan, stabilitas, dan keindahan; (3) gaya emosi (emotion), yaitu gaya yang berangkat dari keyakinan bahwa fungsi utama dari seni visual adalah menciptakan bentuk-bentuk yang tidak mampu direkam kamera, yaitu getaran emosi; dan (4) gaya fantasi, yaitu, gaya yang memi- liki kecenderungan/identik dengan bentuk-bentuk yang hanya ada di alam mimpi.

Tahap kedua dalam kajian ini disebut tahap analisis ikonografis, yaitu proses membaca arti sekunder dari aspek tekstual (ciri-ciri visual/motif artistik) dengan melihat hubungan antara ciri visual sebuah karya seni dengan tema dan konsep berdasarkan interpretasi dari imaji atau gambar, cerita, dan alegori (kiasan atau perlambangan). Untuk itu, diperlukan kajian-kajian kepustakaan sebagai pendukung berupa berbagai teori seperti antropologi, sosiologi, sosial-budaya, atau gaya hidup, karya-karya sastra, dan filsafat sesuai konteks karya yang dikaji. Tema atau konsep yang spesifik diekspresikan oleh objek karya seni dan kejadian (events) di dalam karya tersebut. Pada tahap ini menggunakan prinsip korektif sejarah tipe. Untuk itu, perlu diperbandingkan dengan karya lain, dalam hal ini akan dibandingkan dengan karya Agus Djaya yang berjudul Ronggeng. Pemilihan karya Agus Djaya sebagai pembanding, berdasarkan kesamaannya dengan Sudjojono di Persagi. Juga karya Affandi yang berjudul Ibu (1940). Karya Affandi ini dipilih sebagai pembanding dalam prinsip korektif karena karya ini dibuat dalam masa yang berdekatan dengan karya Sudjojono.

Untuk memperoleh tema atau konsep lukisan DDKT dibutuhkan konfirmasi sumber-sumber literer, di antaranya adalah buku biografi karya Mia Bustam yang berjudul Sudjojono dan Aku. Buku ini merupakan catatan biografi Mia Bustam selama menjadi istri pertama dari S. Sudjojono. Meskipun karya DDKT dibuat sebelum menikah, di dalam buku ini memuat kisah-kisah masa lalu dari Sudjojono. Selanjutnya novel Bumi Manusia yang ditulis oleh Pramoedya Ananta Toer. Novel ini merupakan bagian pertama dari tetralogi yang ditulis oleh Pramoedya. Dengan mengambil setting tahun awal 1900-an sampai revolusi, novel ini mampu menggambarkan dengan rinci situasi sosial, budaya, politik, pandangan hidup, dan mental masyarakat pada waktu itu. Dengan gaya bahasa yang lugas Pramoedya tidak melewatkan setiap detail dari hal-hal yang sifatnya fisik seperti gambaran mengenai rumah tinggal, arsitektur dan perlengkapannya, pakaian, adat kebiasaan, sopansantun, dan lain sebagainya sehingga tepat untuk 
dijadikan referensi pendukung.

Pada tahap ikonografi ini juga akan dilacak mengenai gaya hidup masyarakat pada masa 19301940-an. Referensi-referensi lain yang berkaitan dengan gaya hidup antara lain buku karya Djoko Soekiman (2011) yang berjudul Kebudayaan Indis. Ia memaparkan lebih detail mengenai kebudayaan yang diakibatkan kontak antara bangsa Belanda dan kaum pribumi yang disebutnya sebagai kebudayaan Indis. Pemaparan ini digunakan untuk menganalisis simbol-simbol yang terdapat di dalam lukisan Sudjojono.

Tahap ketiga, disebut juga tahap interpretasi ikonologis, yaitu tahapan untuk memberikan makna intrinsik atau simbolik yang subtil atau mendasar dari objek karya seni agar bisa memastikan prinsip-prinsip filosofis karya seni pada suatu zaman. Pada tahap ini diperlukan intuisi sintetik berdasar pada kondisi psikologis dan weltanschauung atau pandangan hidup dari pengamat. Prinsip korektif pada tahapan ini menggunakan gejala-gejala budaya sesuai konteks dari objek. Pada tahapan ini, pemaknaan terhadap lukisan DDKT akan dilakukan dengan menggunakan teori simbol dari Suzanne K. Langer.

Menurut Langer (Yulimarni, 2011) simbol dibedakan menjadi dua jenis, yaitu simbol seni dan simbol di dalam seni. Simbol seni disebut juga dengan bentuk ekspresi, sebagai ekspresi dari jalinan antara sensibilitas, emosi, perasaan, dan kognisi impersonal, yang merupakan ciri utama dari karya seni. Simbol seni dikatakan juga sebagai citra absolut (tidak terbatas), citra yang sebaliknya akan menjadi irasional karena secara harfiah tidak tergambarkan. Sementara yang dikatakan simbol di dalam seni adalah arti perlambangan yang dimuatkan pada karya tersebut atau sebuah metafora, sebuah citra dengan signifikansi harfiahnya yang jelas ataupun tersamar. Dengan demikian, menurut Langer dalam seni adalah sebuah simbol dan sekaligus juga bermuatan simbol.

Untuk memahami gejala-gejala kultural akan latar sosial masyarakat Batavia tempat Sudjojono tinggal dan berkarya, penulis menggunakan referensi mengenai kaitan antara gaya hidup dengan kelas sosial dalam buku karya Sartono Kartodirdjo yang berjudul Perkembangan Peradaban Priyayi dan buku karya dari hasil penelitian Agus Burhan (2009) yang telah diterbitkan menjadi buku berjudul Perkembangan Seni Lukis Mooi Indie sampai Persagi di Batavia, 1900-1942.

Menurut Sartono Kartodirdjo (1987: 53) gaya hidup adalah suatu totalitas dari pelbagai tata cara, adat kebiasaan, struktur kelakuan, kompleks lambang-lambang, sikap hidup serta mentalitas dari suatu golongan sosial yang secara menyeluruh memengaruhi kehidupannya sehari-hari. Gaya hidup sebagai suatu totalitas menunjukkan suatu koherensi, tidak lain karena kesemuanya dijiwai oleh suatu etos serta pandangan hidup yang sama dalam suatu kelompok masyarakat.

Gaya hidup merupakan suatu fungsi dari stratifikasi sosial, yaitu sebagai petunjuk perbedaan ataupun garis pemisah antargolongan. Dengan kata lain, melalui pemilihan simbol-simbol yang mencirikan suatu gaya hidup seperti rumah tinggal, kendaraan, pakaian, makanan, sopan-santun, dan gaya bahasa bisa menunjukkan kelas sosial seseorang atau sekelompok orang. Secara keseluruhan pendekatan ikonografi dalam makalah ini akan dibingkai dengan pendekatan mengenai gaya hidup dan sosiohistoris.

\section{Praikonografi “Di Depan Kelamboe Terboeka"}

Lukisan "Di Depan Kelamboe Terboeka" (DDKT) karya Sudjojono yang berangka tahun 1939 objek utamanya adalah sosok perempuan. Pada latar depan, tampak sosok perempuan, rambutnya terjurai lepas, dengan kebaya bermotif bunga-bunga kecil berwarna-warna cerah, dibalut kain jarik berlatar warna hitam dengan motif batik tumpal berwarna merah menyala di pinggir kain, terjuntai ke bawah sampai batas mata kaki, duduk dengan posisi gelisah, dan tampak tak nyaman. Sebelah tangan tersampir pada bahu kursi dan tangan satunya lagi menumpu di kursi kayu berwarna cokelat seperti sedang menyangga beban berat.

Paduan warna cerah kuning, merah, dan hijau dari kebaya yang dipakai tidak mampu menutupi kegalauan dan kelelahan yang memancar dari tatapan sepasang mata hitam milik perempuan itu. Corak bunga-bunga kecil yang menghiasi kebaya 
tersebut juga tidak sanggup memberi nuansa ceria dalam lukisan ini. Hal yang paling mencolok dari lukisan ini adalah wajah pucat dari perempuan itu, tampak sepasang mata hitam yang menatap lurus ke depan. Tatapan matanya tampak lelah menanggung kepedihan dan kemarahan. Bibirnya pun terkatup rapat. Raut mukanya pucat. Di bagian atas kepala perempuan tersebut diisi dengan warna merah menyala dalam goresan yang bebas-lepas dan kuat cenderung liar.

Di latar belakang, bagian atas kepala perempuan tersebut diisi dengan warna merah menyala dalam goresan yang bebas-lepas dan kuat cenderung liar, tampak kelambu (jaring untuk nyamuk yang berbentuk tenda dipasangkan menutup bagian atas tempat tidur) berenda warna putih yang sedang tersibak dengan pengait sepasang bunga berkelopak kecil, berdaun hijau, dan berpita merah memberikan impresi romantic, tetapi muram dan sedih serta kesepian yang mencekam. Suatu kontras dengan penggambaran perempuan di latar depan yang terkesan dingin dan terkurung rasa sepi. Dalam lukisan tersebut terdapat empat buah tanda tangan dari pelukisnya "SS 101", keterangan tempat "Djakarta" dan berangka tahun 1939.

Warna-warna dalam lukisan ini tampak kuat dan kontras, hasil campuran warna yang suram, merupakan jalinan dari warna merah, putih, kuning, hijau yang dikomposisikan juga dengan warna coklat tua. Pemilihan warna yang kuat didukung oleh goresan kasar mampu meredam kontras warna dan memunculkan kesatuan yang harmonis. Penempatan warna juga memberikan efek keruangan sehingga terasa oleh penulis bahwa sosok perempuan tersebut sedang dilukis dalam sebuah kamar tidur dengan kelambu terbuka di latar belakang. Garis-garis yang digoreskan secara bebas dan imajinatif membentuk bidang-bidang dan bentuk objek yang dinamis. Karakteristik garis dalam lukisan ini mempunyai spontanitas yang tinggi dengan tarikan panjang-panjang mengalir tanpa hambatan.

Garis dalam seni lukis mempunyai peran yang penting. Garis dapat merupakan batas suatu benda sekaligus juga memancarkan ekspresi dari pelukisnya. Cat yang digoreskan secara kasar dan tumpuk-menumpuk atau impasto pada lukisan tersebut juga memunculkan efek berupa daya raba atau tekstur kasar. Tampak Sudjojono tidak berkehendak untuk mengejar ketepatan bentuk objek secara proporsional dan ideal sebagaimana yang tertangkap oleh mata kita. Akan tetapi, lukisan ini terasa mempunyai ritme dan elan vital.

Untuk memperoleh kepastian mengenai gaya lukisan, pada tahapan ini juga akan diperbandingkan dengan karya-karya S. Sudjojono yang lain, yaitu Ibu (1935), Tjap Go Meh (1940), dan Potret Tetangga (1947). Perbandingan ini untuk melihat gaya Sudjojono. Dalam karya Ibu yang dibuat pada tahun 1935 lukisan lebih realistik, meskipun demikian sudah terlihat kuat ekspresi dari wajah seorang ibu yang terlihat muram dan sedih.

Meskipun mempunyai perbedaan dalam tema lukisan, dalam karya Tjap Go Meh juga ditemukan suatu konsistensi dan kesesuaian aspek-aspek visual dengan lukisan sebelumnya seperti goresan garis dan aspek kebentukan. S. Sudjojono mengungkapkan emosinya dengan meluap-luap. Pada latar depan, terlihat seorang wanita dalam tarian dan gandengan seorang bertopeng, diapit oleh seorang laki-laki yang berdasi dan seorang pemusik bertopeng buaya. Di sisi lain ada seorang kerdil yang berdiri tegak termangu-mangu, sedangkan di latar belakang berombak masa yang berarak dan menari dalam kegembiraan. Wajah-wajah dalam lukisan tersebut hadir dalam bentuk-bentuk yang tidak lazim. Demikian juga dengan bentuk tubuh yang tidak mengejar proporsi ideal penggambaran manusia. Umumnya mengalami deformasi seperti bibir yang dipanjangkan dan hampir semua sosok dalam lukisan tersebut mengenakan semacam topeng.

Walaupun lukisan ini berukuran kecil, Sudjojono benar-benar telah mengekspresikan situasi yang penuh kegembiraan, namun juga ada ironi dan suatu sikap kritis penuh sindiran. Dalam Tjap Go Meh ini terlihat spontanitas yang meluap tinggi. Deformasi orang-orang dalam arakan dan warna-warnanya yang kuat, mendukung seluruh ekspresi dari perayaan Tjap Go Meh. Dalam lukisan Potret Tetangga (1947) aspek kebentukan semakin realistik, tetapi kita masih bisa merasakan kekuatan ekspresi kemuraman dari seorang bapak yang merupakan tetangga Sudjojono ketika tinggal di daerah Prambanan Yogyakarta. 

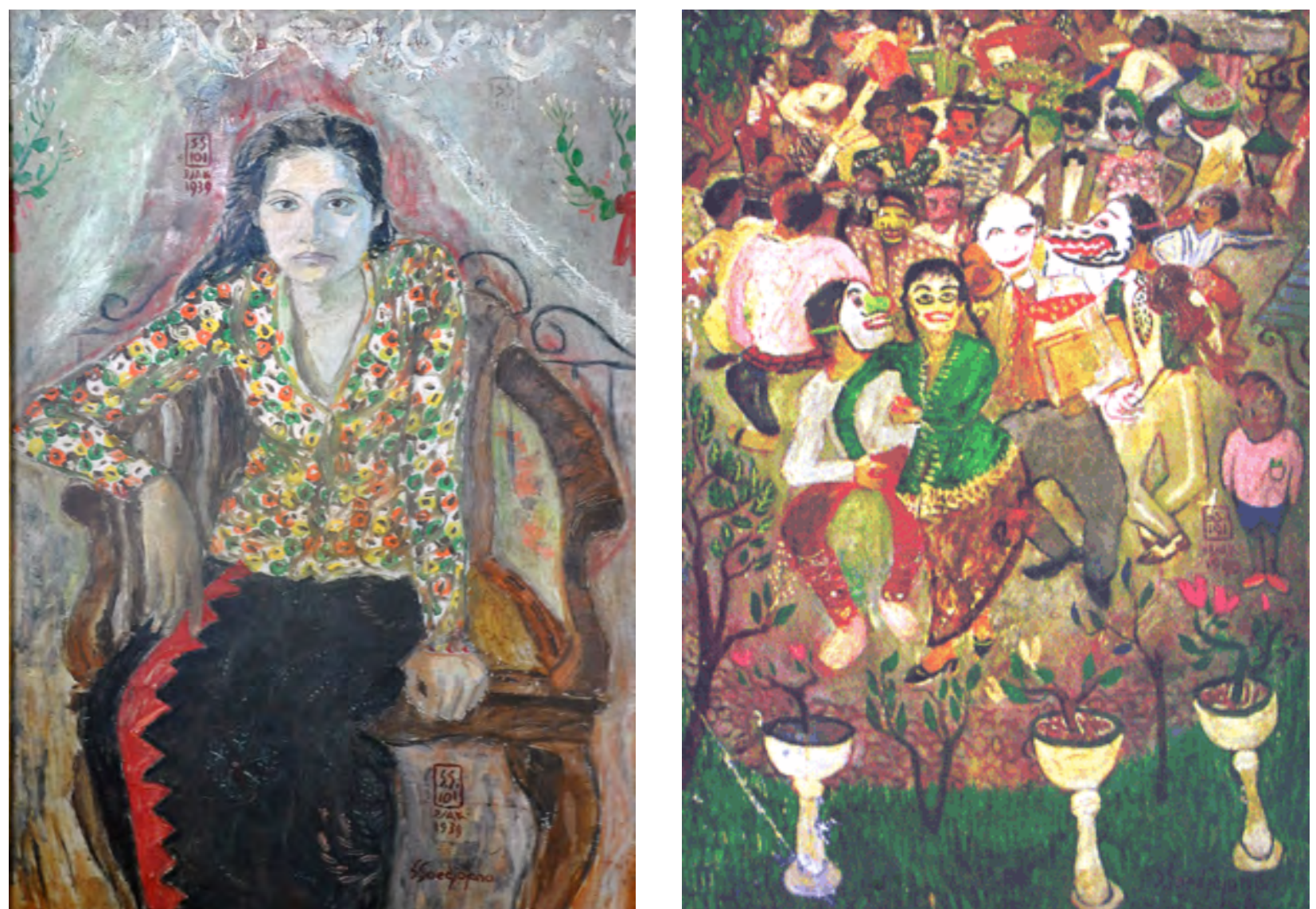

Gambar 1. Perbandingan antara karya Sudjojono Di Depan Kelamboe Terboeka (1939, cat minyak di atas kanvas) dan Tjap Go Meh (1940, cat minyak di atas kanvas, $73 \times 51 \mathrm{~cm}$ ). Sumber : Dokumentasi Mikke Susanto
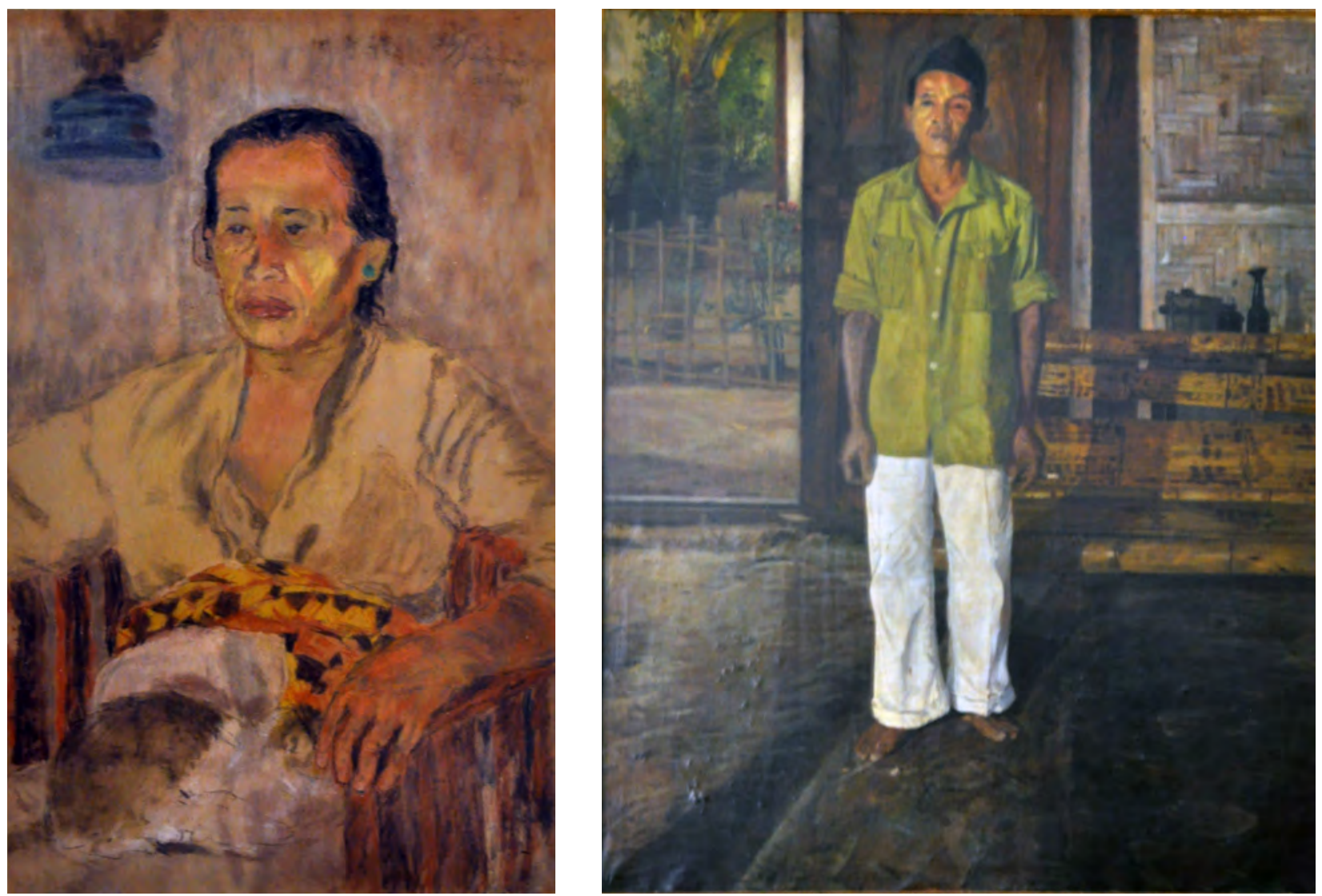

Gambar 2. Perbandingan antara karya Sudjojono Ibu (1935) dan Potret Tetanggaku (1947).

Sumber : Dokumentasi Mikke Susanto 
Berdasarkan analisa formal tersebut dan proses komparasi dengan karya Sudjojono yang lain kemudian dikoreksi menggunakan teori mengenai gaya. Merunut pada teori gaya yang dikemukakan oleh Feldman, gaya lukisan DDKT ini bisa dikategorikan ke dalam gaya emosi yang bisa dilacak dari aspek kebentukan. Bentuk-bentuk dalam karya Sudjojono tersebut tidak mengejar ketepatan bentuk-bentuk yang ideal dan halus sebagaimana lukisan realistic, tetapi lebih mengutamakan kekuatan ekspresi dari objek gambar. Hal ini dibuktikan dengan penggunaan garis yang spontan, mengalir, bebas-lepas tanpa hambatan. Fungsi utama dari unsur-unsur visual dari lukisan tersebut adalah untuk menciptakan bentuk-bentuk yang tidak mampu direkam kamera, yaitu getaran emosi.

Selanjutnya Feldman juga menyatakan bahwa gaya juga bisa diklasifikasikan menurut tekniknya. Berdasarkan teknik yang digunakan gaya lukisan Sudjojono di atas bisa dikategorikan sebagai gaya ekspresi yang merupakan implementasi dari aliran ekspresionisme. Canaday (1962: 360) menjelaskan bahwa lukisan ekpresionis adalah kebebasan dalam melakukan distorsi dari bentuk dan warna untuk mengejar ekspresi dari sensasi dari dalam dan emosi. Ekspresionisme terutama berkaitan dengan intensi, perasaan personal, pathos (kepedihan), untuk menggambarkan tragedi, kekerasan, dan hal-hal yang mengerikan.

\section{Ikonografi "Di Depan Kelamboe Terboeka”}

Pada tahap kedua atau tahap ikonografi berupa identifikasi makna sekunder yang bersumber dari pembacaan aspek-aspek tekstual karya seni dan melihat hubungannya dengan konteksnya untuk memperoleh pemahaman mengenai tema dan konsep karya tersebut. Sebagai prinsip korektif dibutuhkan pembandingan dalam sejarah tipe. Tema diartikan sebagai suatu sumber penciptaan yang menarik minat seorang seniman dan menjadi atau dijadikan sebagai pengutamaan studi seninya. Pada akhirnya suatu tema menjadi konsepsi tentang apa saja dari seniman yang disampaikan atau diamanatkan melalui karya seninya (Burhan, 2003). Konsep sendiri menurut Yulimarni (2011) merupakan upaya filosofis untuk menggali pemikiran dan penciptaan yang mendasari terbentuknya suatu objek seni, dengan cara menguraikannya menjadi komponen-komponen terpisah dan setiap komponen ditetapkan sifat-sifatnya serta kegunaannya.

Tahap kedua ini akan dimulai dengan memahami aspek konteks karya DDKT yang kemudian dianalisis bagian-bagian dari karya seni yang mempunyai keterkaitan dengan tipe-tipe pada zaman tersebut. Karya Sudjojono juga akan dikomparasikan dengan karya dari seniman yang sezaman dengan Sudjojono, yaitu karya Agus Djaya yang berjudul Ronggeng dan karya Affandi yang berjudul Ibu (1941).

Pembacaan terhadap lukisan DDKT dengan menggunakan pendekatan ikonografi harus juga didukung oleh bukti-bukti literer. Karya Sudjojono yang berangka tahun 1939 ini dibuat dalam situasi masyarakat Indonesia sedang berjuang melawan penjajahan. Masa penuh kesulitan dan kemiskinan di mana-mana terutama di kalangan masyarakat yang berada di desa-desa atau perkampungan. Kondisi sulit akibat penjajahan tersebut mendorong munculnya patologi sosial. Tidak sedikit orang-orang yang berbondong-bondong pindah ke perkotaan untuk mengadu nasib atau tetap memilih tinggal di desa dan pasrah serta terjebak dalam kemiskinan yang pahit. Bagi sebagian orang yang oportunis, situasi tersebut juga dimanfaatkan untuk mencari keuntungan dengan cara mendekati pihak-pihak yang sedang berkuasa dan mempunyai kemampuan ekonomi terutama kaum penjajah Belanda atau para bangsawan. Beragam cara dilakukan orang untuk mendapatkan uang dan menaikkan derajat sosial. Seperti yang tergambar dalam novel karya Pramoedya, Bumi Manusia, seorang gadis desa bernama Sanikem atau Ikem anak seorang juru tulis Sastrotomo yang dijual oleh orang tuanya seharga 25 gulden untuk menjadi gundik orang Belanda bernama Herman Mellema.

Kisah dalam novel tersebut tidak jauh berbeda dengan kesaksian dari Mia Bustam berkenaan dengan sosok perempuan dalam lukisan Sudjojono. Menurut Mia Bustam, sosok perempuan dalam lukisan DDKT bernama Adhesi, seorang perempuan yang lari ke Batavia dari rumahnya karena dijual atau dipaksa menikah dengan seorang haji di daerah Cirebon. Ketidakberdayaan Adhesi mem- 
bawanya untuk menjadi pelacur di daerah Pasar Senen yang membuatnya bertemu dan berkencan dengan Sudjojono. Seperti yang dikatakan oleh Sudjojono dalam buku Mia Bustam (2006:48-49):

"Aku (Sudjojono) kemudian menjadi langganan tetap, karena tertarik oleh kisah hidupnya. Ia gadis berasal dari Cirebon yang dipaksa kawin dengan seorang haji. Ia kemudian melarikan diri, terdampar di Jakarta, dan masuk di dunia pelacuran. Aku terpikir untuk mengentaskannya dari dunia nafsu, dan kuajak dia agar mau hidup bersamaku. Ia tidak menolak kubawa ke Sunter. Sejak itu, untuk menghapus kenangan dan jejak hidupnya yang lalu, namanya kuganti dengan Miryam. Tapi bapak dan ibu menjadi gempar, marah, dan sedih sehingga mereka menjadi sangat kurus".

Dalam situasi yang sulit, dekade 1930-an juga ditandai dengan munculnya gairah terhadap zaman baru. Hal ini sebenarnya sudah dirintis dan terbangun sejak awal abad ke-20 di Hindia Belanda. Ditandai oleh munculnya pergerakan nasional yang dimotori oleh kelas menengah yang memperoleh pendidikan dari Belanda. Penjajahan Belanda yang mengakibatkan kemiskinan, penindasan, dan penderitaan batin bagi masyarakat telah mendorong sejumlah orang untuk bergerak mencari perspektif baru. Kaum nasionalis muncul dan berkembang dari pelbagai bidang, termasuk kebudayaan dan kesenian. Latar sosial seperti itulah yang turut memengaruhi Sudjojono untuk mengadakan pergerakan nasional di bidang seni lukis.

Agus Burhan (2008) dalam bukunya yang berjudul Perkembangan Seni Lukis Mooi Indie sampai Persagi di Batavia, 1900-1942 menyebutkan bahwa di bidang kebudayaan dan kesenian pun tidak mau ketinggalan untuk mencari suatu corak seni lukis yang mencerminkan identitas kebudayaan Indonesia. Pada masa-masa sebelumnya seni lukis Indonesia didominasi oleh karya-karya yang banyak terpengaruh oleh seni lukis dari Barat terutama yang beraliran romantisisme. Umumnya lukisan-lukisan tersebut memuat keindahan alam Indonesia terdiri dari hamparan sawah, aliran sungai dan gunung yang menjulang kebiru-biruan di kejauhan. Selain lukisan pemandangan juga lukisan potret yang menggambarkan kecantikan, keekso- tisan, dan kekuasaan serta kemewahan golongan atas masyarakat Hindia Belanda.

Pada masa-masa tahun 1930-1940-an muncul suatu kebudayaan Indis, yaitu percampuran antara kebudayaan yang dibawa oleh bangsa Belanda dengan budaya asli penduduk pribumi. Kebudayaan tersebut muncul akibat kontak yang lama dan intensif antara bangsa Belanda dengan penduduk pribumi. Kebudayaan ini menyebar dan tampak pada berbagai macam unsur kebudayaan seperti pada bahasa, kelengkapan hidup, kesenian, arsitektur, pendidikan, gaya pakaian, ilmu pengetahuan, dan lain-lain. Kebiasaan-kebiasaan tersebut kemudian diadopsi dan menjadi bagian dari gaya hidup golongan tertentu masyarakat Hindia Belanda. Gaya hidup sendiri adalah suatu totalitas dari pelbagai tata cara, adat istiadat, struktur kelakuan, kompleks lambang-lambang, sikap hidup serta mentalitas dari suatu golongan sosial yang secara menyeluruh memengaruhi kehidupannya sehari-hari. Sebagai suatu totalitas menunjukkan suatu koherensi, tidak lain karena semuanya dijiwai oleh suatu ethos serta pandangan hidup yang sama (Soekiman, 2011: 19-20).

Pemahaman mengenai gaya hidup dari kebudayaan Indis dibutuhkan untuk memahami dan melakukan prinsip korektif sejarah tipe pada simbol-simbol yang terdapat dalam lukisan Di Depan Kelamboe Terboeka. Dalam lukisan tersebut terdapat sosok perempuan yang mengenakan kebaya dan jarik duduk di atas kursi dengan kelambu di latar belakang. Pada masa tersebut, umumnya perempuan mengenakan kebaya sebagai pakaian sehari-hari. Seperti tampak dalam foto yang menunjukkan seorang perempuan (Ibu Fatmawati Soekarno) di depan sebuah mikrofon. Soekiman (2011: 30) menyebutkan dalam bukunya bahwa pakaian dan kelengkapannya dalam kebudayaan Indis, banyak dipengaruhi oleh kebudayaan Eropa, sedangkan masyarakat pribumi, yaitu pembantu rumah tangga, para nyai, kaum perempuan indis mengenakan sarung dan kebaya. Kain dan kebaya juga dikenakan untuk pakaian sehari-hari oleh para perempuan Eropa.

Kebiasaan memakai kebaya di kalangan perempuan Hindia Belanda juga disebutkan dalam novel Bumi Manusia, seperti penggambaran 

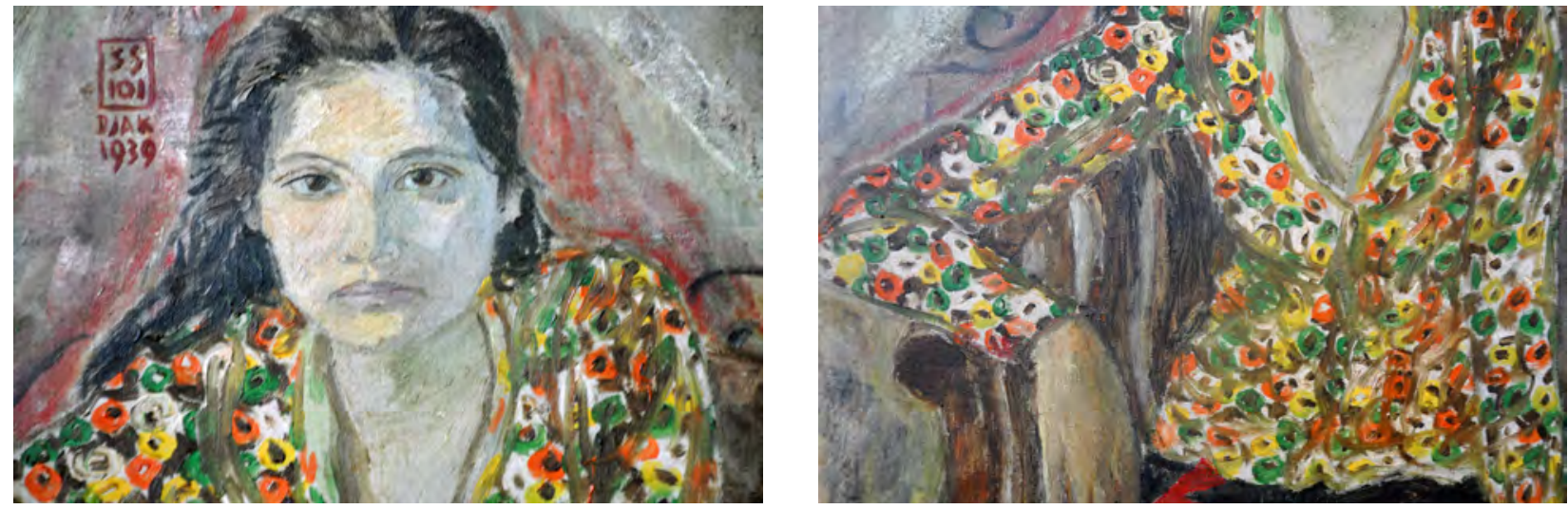

Gambar 3. Kebaya yang dikenakan perempuan dalam lukisan Di Depan Kelamboe Terboeka.

Sumber : Dokumentasi Mikke Susanto

Nyai Ontosoroh yang dikatakan “..... dan segera kemudian muncul seorang wanita pribumi, berkain, berkebaya putih dihiasi renda-renda...." (Pramoedya, 2010: 32). Hal ini juga tampak dalam buku Mia Bustam, ia tidak diperbolehkan memakai pakaian ala Barat oleh Sudjojono. Hal ini terlihat dalam percakapan (Bustam, 2006: 34):

\footnotetext{
"Mengapa tidak boleh (memakai rok)?" tanyaku (Mia Bustam)

"Kau terlalu patut memakai rok-rokmu itu." "Lho, lha malah baik toh?"

"Tapi dengan begitu kau menarik perhatian laki-laki lain. Lalu kau akan direbutnya dariku." "Kok lucu! Apa semua laki-laki lain tukang ngrebut istri orang? Dan apa aku akan mau direbut begitu saja?"

Mas Djon (Sudjojono) tidak menjawab. Tapi karena aku sangat mencintainya aku menurut saja. Semua pakaian non grata aku simpan baik-baik.
}

Kebudayaan Indis juga terlihat pada perlengkapan rumah tangga, seperti meja, kursi, dan almari yang merupakan barang baru dikenal oleh suku Jawa setelah orang Eropa datang di Nusantara. Kemudian golongan bangsawan dan priyayi mulai menggunakan peralatan rumah tangga tersebut yang kemudian disebut meubelair. Sementara itu rakyat kebanyakan tetap menggunakan peralatan rumah tangga yang sederhana, misalnya tikar sebagai alas duduk. Selain para priyayi yang menggunakan peralatan rumah tangga berupa almari, meja kursi dan ranjang berkelambu adalah orang Indo dan masyarakat timur asing (Cina, Arab dan sebagainya). Perabotan rumah tangga atau meube- lair tersebut berbahan dasar kayu jati berkualitas baik dengan ukiran motif bergaya Jawa atau bercampur dengan motif bergaya Eropa (Soekiman, 2011:30). Mengenai perabotan Mia Bustam juga bercerita bahwa pada masa itu setelah menikah dengan Sudjojono mereka berbelanja perabotan rumah:

"Pada hari Minggu berikutnya kami pergi berbelanja, mencari perabot pengisi rumah. Satu setel meja makan dengan enam kursi dan satu lemari makan seharga 65 rupiah. Satu lemari

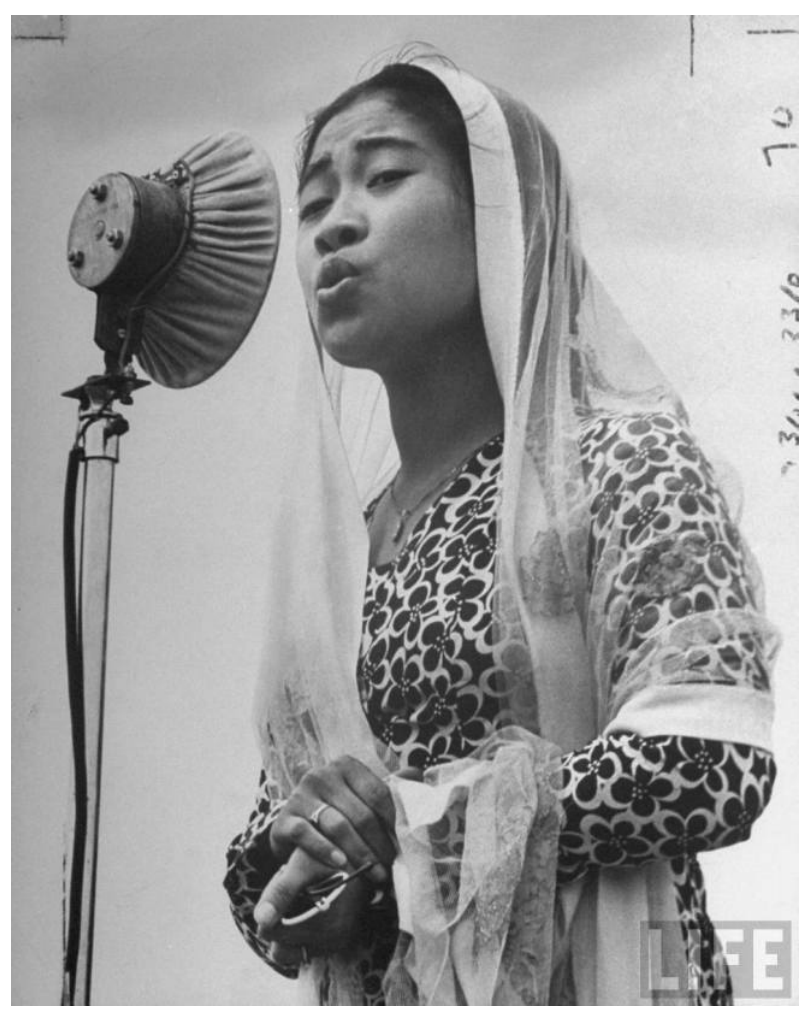

Gambar 4. Perempuan (Ibu Fatmawati Soekarno) menggunakan kain kebaya dengan motif bunga-bunga kecil pada tahun 1940-an. Sumber : Dokumentasi Mikke Susanto 
pakaian besar seharga 15 rupiah, meskipun barang bekas tapi kuat dan bagus bentuknya. Satu setel kursi rotan dengan bantalan berwarna terracota seharga 35 rupiah....." (Bustam, 2006: 32)

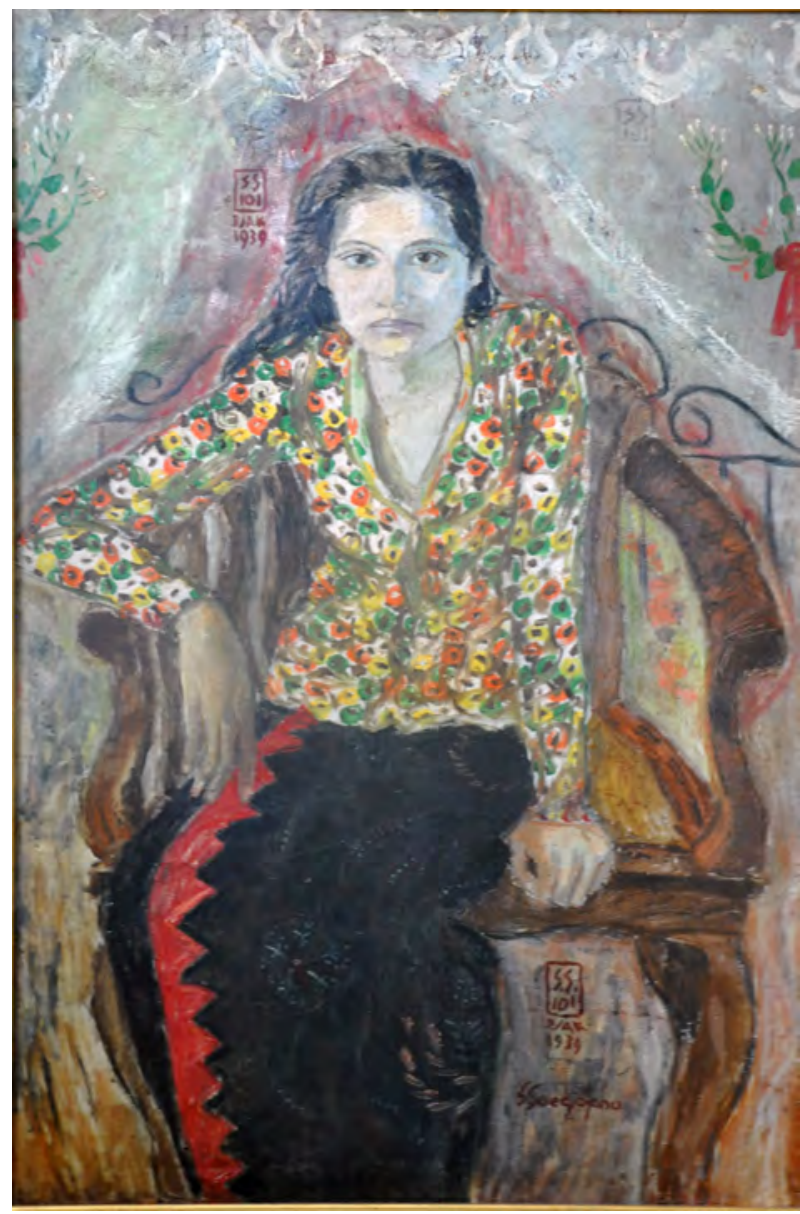

Gambar 5. Kursi dalam lukisan Di Depan Kelamboe Terboeka berwarna cokelat, merujuk pada kursi yang terbuat dari bahan dari kayu. Sumber : Dokumentasi Mikke Susanto

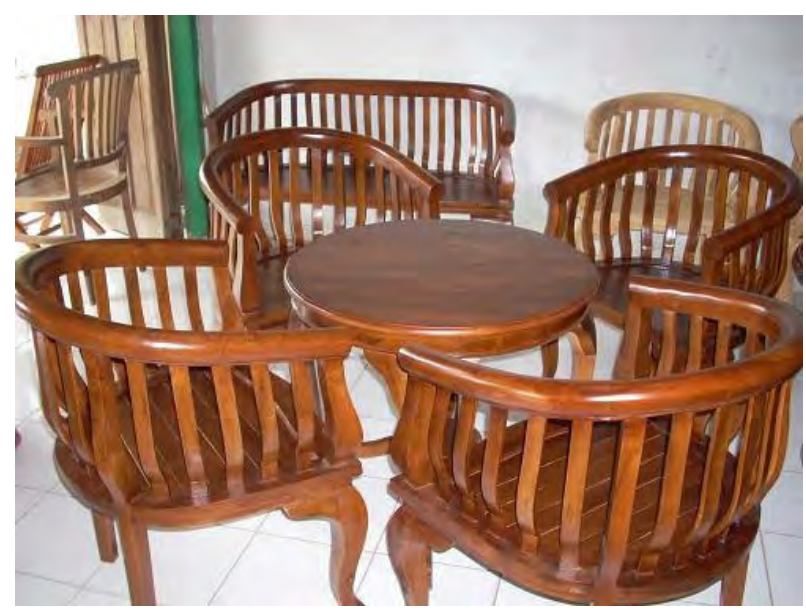

Gambar 6. Kursi Betawi yang biasa digunakan masyarakat Hindia Belanda. Sumber: www.google. co.id/imgres?q=kursi+lenong+betawi+kuno. Di akses pada tanggal 10 Januari 2011.

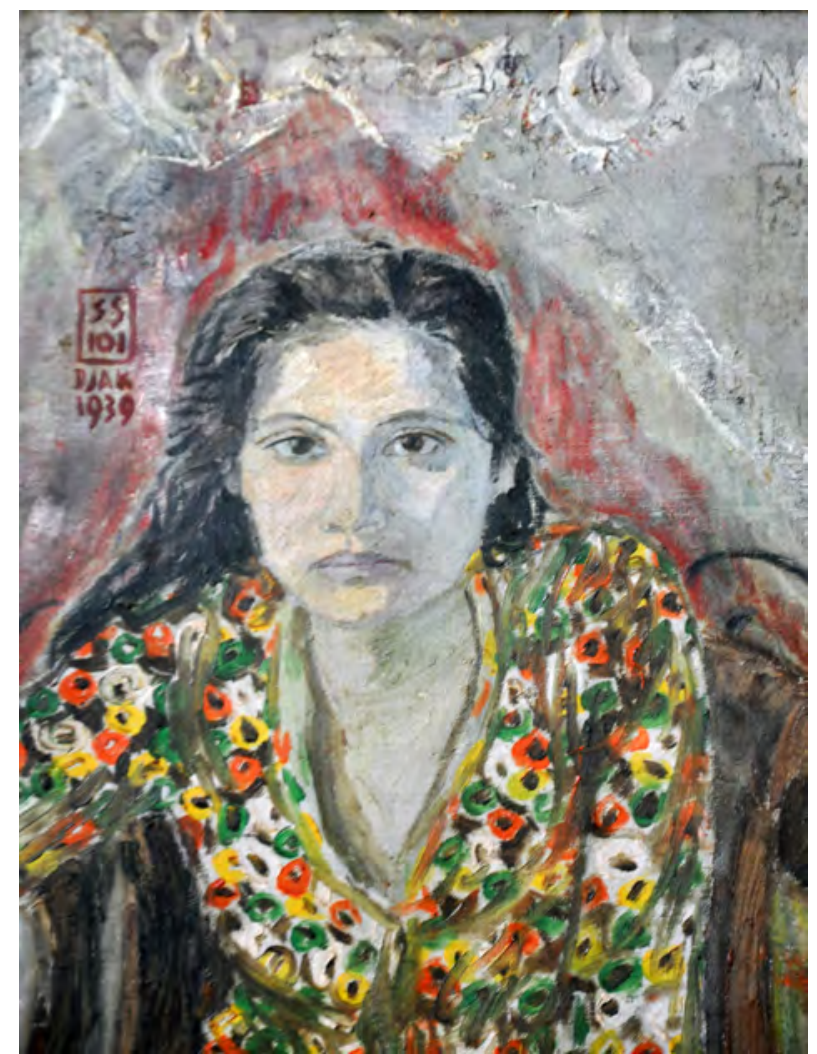

Gambar 7. Kelambu dalam lukisan Di Depan Kelamboe Terboeka. Sumber : Dokumentasi Mikke Susanto

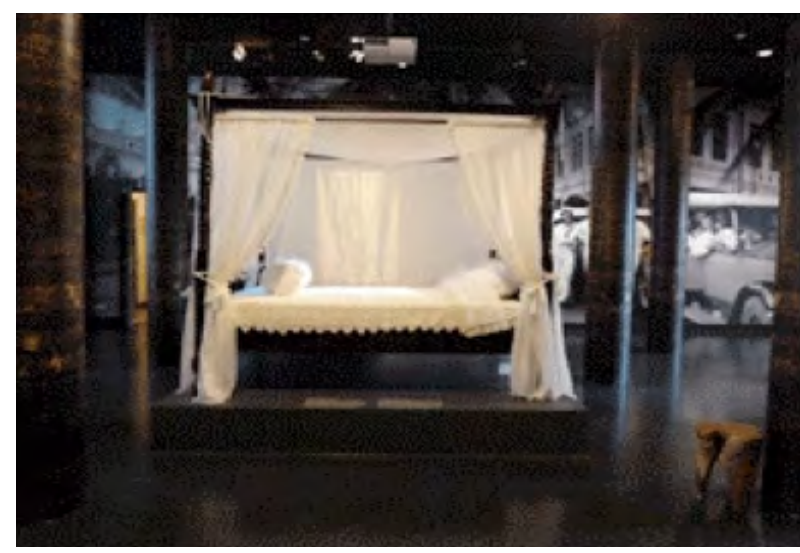

Gambar 8. Ranjang berkelambu di Museum Bronbeek yang biasa digunakan pada zaman Hindia Belanda untuk melindungi dari gigitan nyamuk. Sumber: http:// kolomkita.detik.com/baca/artikel/2/2027/sejarah_ hindia_belanda_di_belanda. Diakses pada tanggal 10 Januari 2012.

Gambar 5 merupakan gambar dari kelambu dan kursi yang setipe dengan visual yang terdapat dalam lukisan DDKT.

Motif batik tumpal banyak dipengaruhi oleh kebudayaan India di pesisir Jawa mulai pada abad ke-19. Kain batik dengan motif tumpal ini banyak diperdagangkan oleh para pedagang Cina dan India di kota-kota pantai Jawa dan Sumatra, seperti 


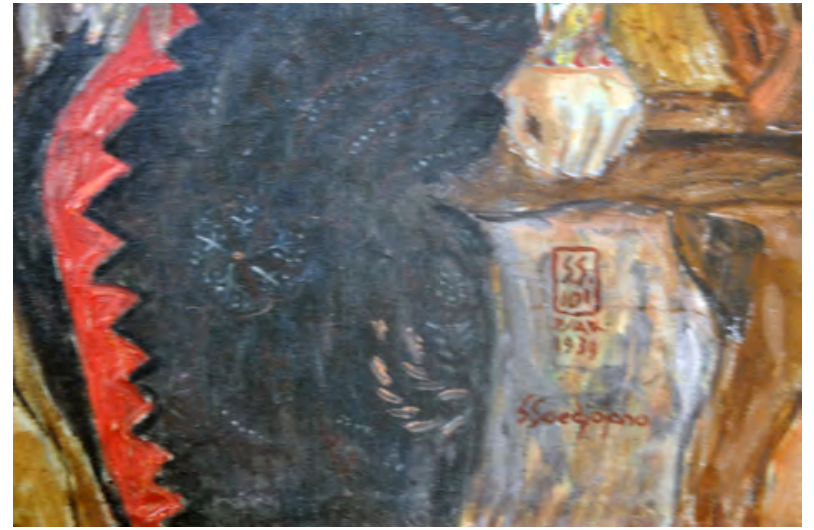

Gambar 9. Motif Batik Tumpal dalam lukisan Di Depan Kelamboe Terboeka. Sumber : Dokumentasi Mikke Susanto

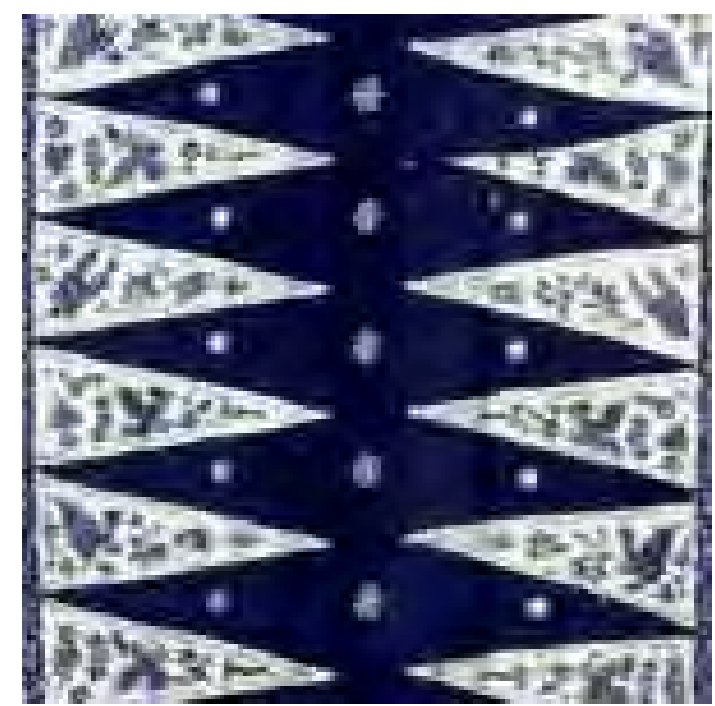

Gambar 10. Motif Batik Tumpal biasa digunakan perempuan daerah pesisir. Sumber: http://elyshashalies1. blogspot.com.

Semarang khususnya Cirebon dan Lasem. Motif batik tumpal ini memiliki kedekatan tipe dengan motif batik yang dikenakan oleh perempuan dalam lukisan Di Depan Kelambu Terbuka. Dalam novel Bumi Manusia juga digambarkan Sanikem (Nyai Ontosoroh) sebelum berangkat ke rumah Herman Mellema membawa harta benda berupa pakaian kebaya dan kain batik yang jumlahnya lebih dari enam buah (Toer, 2010:121).

Agus Djaya merupakan salah seorang pendiri Persagi bersama-sama dengan Sudjojono. Pandangan seni lukis dari persagi adalah menekankan kejujuran menangkap realitas kehidupan, merupakan elemen yang dialogis dengan semangat nasionalisme akibat kepahitan situasi kolonial. Ungkapan atau kredo yang terkenal dari Soedjojono adalah mewujudkan kesenian sama dengan memperlihat- kan 'jiwa ketok' atau ekspresi yang terlihat. Oleh karena itu, ia sangat menekankan bahwa lukisan yang baik harus terasa kuat gerakan pensilnya. Lukisan yang berkualitas baik tidak harus halus. Lewat goresan pensil dan kuas, seorang pelukis bisa mengungkapkan jiwanya dan sekaligus diketahui kemampuannya. Berbagai ungkapan kredo teknik tersebut sebenarnya juga merupakan fenomena pemberontakan pelukis ekspresionisme yang ingin mengungkapkan kepekatan hati akibat situasi sosial yang penuh ketimpangan dan kepahitan. Selain itu, pandangan seni ini menolak konsep estetis dari lukisan mooi indie yang pada masa itu mendominasi (Burhan, 2008:73-74).

Dalam karya Agus Djaya terdapat kesamaan dengan karya Sudjojono yang menghadirkan sosok perempuan dalam lukisannya. Dilacak dari sejarah tipe pakaiannya, perempuan dalam lukisan Sudjojono berasal dari masyarakat menengah ke bawah, sedangkan dalam karya Agus Djaya, sosok ronggeng juga merepresentasikan masyarakat kelas baru. Dalam lukisan Affandi, perbandingan ditujukan pada kualitas ekspresif garis dan emosi yang tertampilkan pada lukisan berjudul Ibu, setipe dengan lukisan Sudjojono.

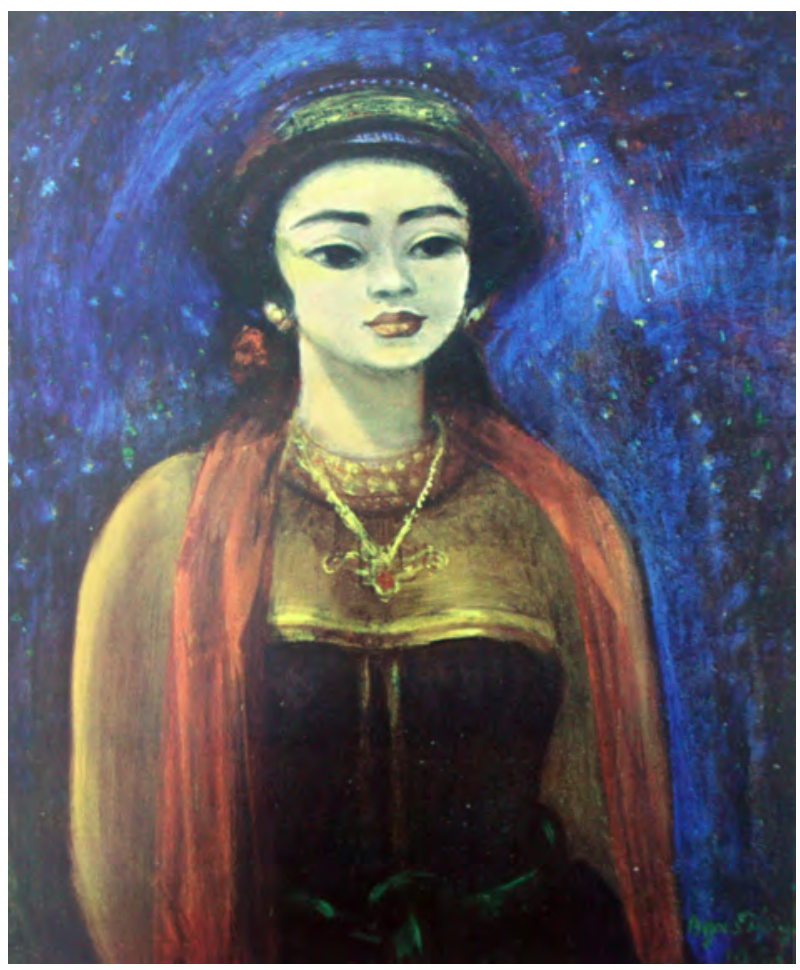

Gambar 11. Foto lukisan Agus Djaya berjudul Ronggeng, cat minyak di atas kanvas $63 \times 73 \mathrm{~cm}$. Sumber: Buku Koleksi Lukisan dan Patung Soekarno, 1964 


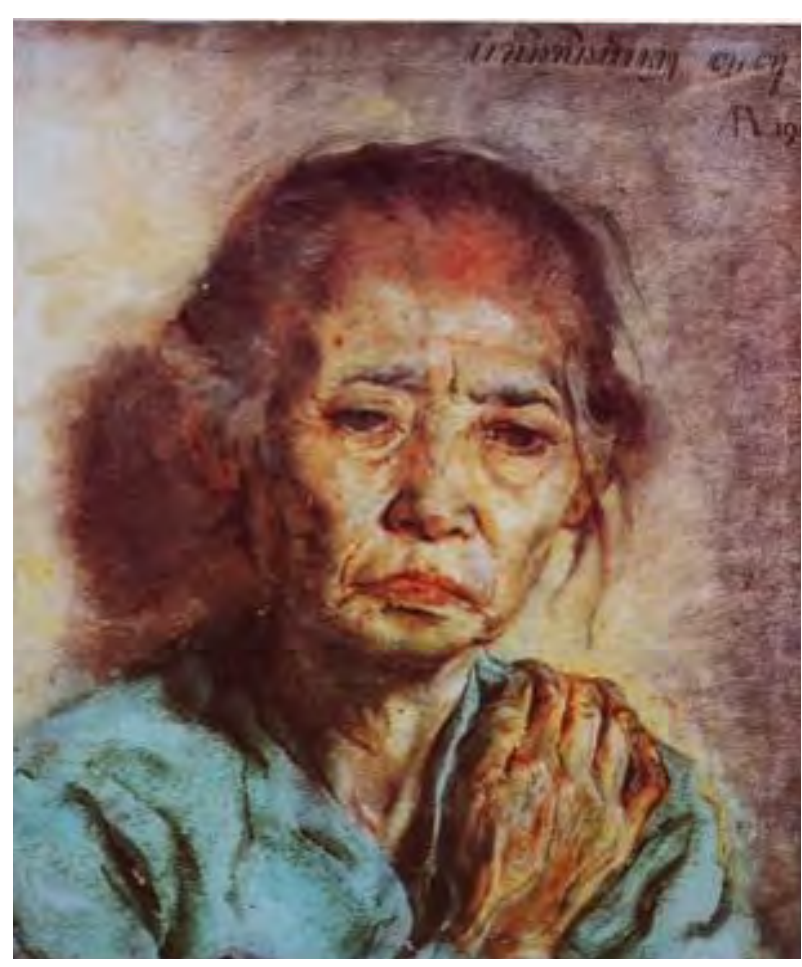

Gambar 12. Foto lukisan Affandi berjudul Ibu (1940). Sumber: Buku Koleksi Lukisan Affandi, 2005

Berdasarkan analisis tersebut, dapat diperoleh simpulan mengenai tema dan konsep lukisan Di Depan Kelamboe Terboeka. Sudjojono ingin menggambarkan realitas masyarakat pada zaman itu sekaligus ironi mengenai ketimpangan sosial dari masyarakat pada waktu itu. Selain itu, juga ingin merumuskan satu corak baru seni lukis yang berbeda dengan lukisan mooi indie. Corak baru tersebut ditandai dengan lukisan yang mampu mengekspresikan emosi dan sensasi batin yang bersimpati pada tema-tema kepedihan tragedi kemiskinan.

\section{Ikonologis "Di Depan Kelamboe Terboeka"}

Pada tahap ini akan dilakukan pemaknaan terhadap karya Di Depan Kelamboe Terboeka (DDKT) berdasarkan intuisi sintetik yang dipengaruhi oleh kondisi psikologi dan pandangan hidup dari penulis. Selain itu digunakan prinsip korektif berupa gejala-gejala kultural. Selain itu juga akan digunakan teori simbol dari Suzanne K. Langer. Menurut Langer, simbol dibedakan menjadi dua jenis, yaitu simbol seni dan simbol di dalam seni. Simbol seni disebut juga dengan bentuk ekspresi, sebagai ekspresi dari jalinan antara sensibilitas, emosi, perasaan, dan kognisi impersonal, yang merupakan ciri utama dari karya seni. Simbol seni dikatakan juga sebagai citra absolut (tidak terbatas), citra yang sebaliknya akan menjadi irasional karena secara harfiah tidak tergambarkan. Sementara yang dikatakan simbol di dalam seni adalah arti perlambangan yang dimuatkan pada karya tersebut atau sebuah metafora, sebuah citra dengan signifikansi harfiahnya yang jelas ataupun tersamar. Dengan demikian, menurut Langer, seni adalah sebuah simbol dan sekaligus juga bermuatan simbol (Yulimarni, 2011).

Pada tahap ketiga ini akan dipaparkan terlebih dahulu situasi sosial yang melatarbelakangi lukisan karya Sudjojono. Sejak abad ke-18 sampai awal abad ke-20 muncul golongan sosial baru sebagai pendukung kuat kebudayaan Indis di daerah jajahan Hindia Belanda. Menurut Kartodirdjo (1987: 11), dalam bukunya Perkembangan Peradaban Priyayi menyebutkan bahwa masyarakat Hindia Belanda terdiri dari: (1) elite birokrasi yang terdiri atas Pangreh Praja Eropa dan pangreh Praja Pribumi, (2) priyayi birokrasi termasuk priyayi ningrat, (3) priyayi profesional (priyayi dibagi dua, ada priyayi gedhe dan priyayi cilik), (4) golongan Belanda dan golongan Indo yang secara formal masuk status Eropa dan mempunyai tendensi kuat untuk mengidentifikasikan diri dengan pihak Eropa, dan (5) orang kecil (wong cilik) yang tinggal di kampung.

Sartono Kartodirdjo menyebutkan bahwa di kalangan masyarakat Jawa tradisional dibedakan antara kaum elit dan orang kebanyakan. Golongan elit di sini terbagi atas bangsawan dan priyayi. Mereka yang tidak termasuk kedua golongan itu disebut wong cilik, termasuk di dalamnya kaum pedagang, perajin, tukang, dan lain sebagainya. Akan tetapi, seiring perkembangan zaman, pembagian kelas tersebut tidak berlaku mutlak dan muncul "homines novi" (orang-orang baru) yang sudah memperoleh pendidikan sehingga mampu melakukan mobilitas vertikal dan menciptakan kelas menengah baru.

Masing-masing kelompok sosial dalam masyarakat mempunyai ciri-ciri tertentu yang dengan jelas menunjukkan perbedaan dengan kelompok sosial lainnya, terutama kelompok sosial dari rakyat kebanyakan. Ciri-ciri yang membedakan terlihat 
dari perbedaan adat sopan-santun dan bahasa juga hal-hal yang berwujud konkret seperti bentuk rumah, tempat kediaman, pakaian, dan gelar pada nama. Simbol-simbol tersebut menjadi gaya hidup yang bisa menjadi penunjuk status sosial.

Agus Burhan, menjelaskan dengan lebih mendetail struktur sosial masyarakat Hindia Belanda di Batavia pada masa 1930-1942, yaitu terdiri dari campuran dari penghuni asli dan pendatang. Lapisan yang pertama adalah lapisan atas atau elit dan priyayi, sedangkan lapisan yang kedua adalah masyarakat kelas bawah. Pada kedua lapisan inilah pendatang-pendatang dari luar yang terpanggil oleh tuntutan ekonomi dan pendidikan meresap pada kelompok masyarakat itu.

Selanjutnya dijelaskan oleh Agus Burhan (2008: 55-57) bahwa di Batavia, masyarakat kelas bawah terdiri dari orang-orang Betawi asli dan para pendatang. Orang Betawi asli yang tinggal di kampung kebanyakan bekerja sebagai petani, perajin kecil, atau tukang kereta sado. Gelombang urbanisasi dan kecilnya diferensiasi serta kesempatan kerja menyebabkan merebaknya kehidupan jalanan seperti pelacuran dan gelandangan. Dari catatan studi tentang buruh di Batavia pada tahun 1937 menunjukkan bahwa rata-rata penghasilan mereka antara 30-35 sen setiap hari yang sebagian besar habis untuk memenuhi kebutuhan makan.

Pada masa itu Sudjojono telah bekerja sebagai pengajar di Ardjoenaschool dengan gaji 35 gulden sebulan sehingga mampu menghidupi dirinya dengan cukup layak. Dia bisa dimasukkan ke dalam golongan masyarakat dengan status sosial priyayi kecil, yaitu kelompok masyarakat terdidik yang mempunyai keahlian spesifik dan bisa menempati posisi sebagai guru. Jadi, tidak mengherankan dengan pendapatannya ia mampu membiayai kesenangannya dalam plesiran ke Pasar Senen dan juga memungkinkan untuk memiliki rumah dengan perabotan yang mencerminkan gaya hidup kelompok priyayi.

Awal abad ke-20 juga ditandai dengan munculnya semangat sivilitas yang masih embrional dan mulai menemukan bentuknya di akhir 1930-an. Semangat tersebut adalah keinginan yang menggelora dari kelompok terdidik masyarakat pribumi untuk merumuskan pergerakan yang bercirikan nasionalisme untuk membebaskan diri dari penjajahan. Kelompok sosial terdididik ini umumnya berasal dari golongan priyayi. Perhatian mereka tertuju pada kesengsaraan hidup, kemiskinan, keterbelakangan pendidikan, dan penindasan. Mereka tidak segan-segan untuk mengerahkan dana, waktu, tenaga untuk kepentingan umum. Sebagai contoh Ki Hadjar Dewantara dengan sekolah rakyatnya Taman Siswa.

Demikian pula halnya dengan Sudjojono yang mewakili suatu golongan masyarakat terdidik. Sudjojono dalam masa Persagi dan masa Jepang berusaha merumuskan seni lukis Indonesia baru, seperti yang sangat kuat disuarakan lewat tulisan-tulisan dan karyanya. Jiwa semangat itu adalah menolak estetika seni lukis Mooi Indie yang hanya mengungkapkan keindahan dan eksotisme saja. Dengan semangat nasionalisme, Sudjojono ingin membawa seni lukis Indonesia pada kesadaran tentang realitas sosial yang dihadapi bangsa dalam penjajahan. Di samping itu, dia ingin membawa nafas baru pengungkapan seni lukis yang jujur dan empati yang dalam dari realitas kehidupan lewat ekpresionisme. Karya-karya Sudjojono mencerminkan kegelisahannya dalam menyelami realitas kehidupan. Gelora kehidupan yang kalut pada masyarakat terbaca dalam lukisannya. Lukisan itu bagai buku penghidupan bagi mereka yang membacanya. Secara keseluruhan lukisan itu mengekspresikan perasaan kemanusiaan yang dalam. Seperti yang dirumuskan oleh Sudjojono:

"Apakah kesenian itu? Untuk menjawab hal ini susah sekali. Sama susahnya dengan memberi keterangan atau jawaban kalau orang bertanya: apakah listrik itu? Orang bisa menangkap dan memakai kekuatan listrik, tetapi menerangkan apa itu listrik sebenarnya orang. Begitu juga kesenian. Untuk menerangkan kesenian itu saya saya tidak bisa, tetapi barangkali saya bisa dengan jalan contoh-contoh dari buah-buah buatan orang yang sampai sekarang diakui sebagai buah kesenian membuka sedikit tabir dunia kesenian sampai bentuk kesenian tadi bisa terlihat. Kalau seorang seniman membuat suatu barang kesenian, maka sebenarnya buah kesenian tadi tidak lain dari jiwanya sendiri yang kelihatan. Kesenian adalah jiwa kethok. Jadi kesenian adalah jiwa (Siregar, 2010:26). 
Rumusan mengenai konsep seni tersebut mewujud dalam karya Di Balik Kelamboe Terboeka yang menggambarkan keberpihakan Sudjojono pada realitas masyarakat pribumi yang tragis. Sudjojono berhasil menghadirkan ekspresi muka seorang perempuan yang lelah menjalani kehidupan, memilih menjadi pelacur untuk menghidupi dirinya daripada dipaksa menikah dengan orang yang tidak dicintai.

Kedua masalah berupa pencarian konsep seni lukis yang baru dan keinginannya untuk mengungkapkan realitas masyarakat dalam lukisan-lukisannya sehingga bisa tercermin jiwa zaman penderitaan dari masyarakat pribumi akibat penjajahan, menempatkan Sudjojono sebagai pemberontak estetika Mooi Indie yang telah mapan dalam kultur kolonial feodal. Dengan demikian, lukisan Sudjojono Di Depan Kelamboe Terbuka, dapat dimaknai sebagai upaya perjuangan pencarian konsep estetika yang bersumber dari konteks masyarakat dan menghasilkan suatu kredo seni sebagai jiwa ketok serta keinginan yang berkobar berlandaskan jiwa nasionalisme. Pencapaian-pencapaian Sudjojono tersebut membuatnya layak disebut sebagai Bapak Seni Lukis Indonesia.

\section{Simpulan}

Melalui kajian ikonografi bisa memperoleh pemahaman terhadap artefak karya seni lukis Di Depan Kelamboe Terboeka (DDKT), baik pada aspek tekstual, kontekstual, maupun pemaknaan yang lebih subtil. Selain itu, juga memberikan pemahaman bahwa karya seni mampu mengungkapkan fakta-fakta sosial dan mental suatu zaman dengan menggunakan konstruksi pengetahuan yang saling berkait dan mendukung. Dalam kajian ini telaah terhadap karya seni lukis Sudjojono memperoleh ikatan dengan konteksnya melalui analisis pada gaya hidup.

Dari analisis formal juga diperoleh simpulan bahwa lukisan karya Sudjojono mempunyai gaya lukisan formal dan ekspresionisme, tetapi mempunyai kekuatan dan perbedaan dengan karya-karya seniman dari Barat karena mampu menghadirkan jiwa jaman masyarakat Hindia Belanda pada masa itu yang berada dalam kondisi penuh penderitaan akibat penjajahan sekaligus juga gejolak nasionalisme untuk mencari suatu konsepsi dan atau corak seni lukis yang baru.

Lukisan DDKT adalah karya seni yang di dalamnya tidak saja memuat bukti-bukti visual hasil pencapaian Sudjojono, tetapi juga menunjukkan pergulatan pemikiran dalam suatu situasi sosial yang didominasi konsep estetika tertentu. Sudjojono mampu merumuskan konsep seni yang berasal dari kejujuran dan kepekaan dalam melihat realitas sosial dan dikenal dengan kredo jiwa ketok.

\section{Ucapan Terima Kasih}

Atas terselesaikannya hasil penekitian ini, penulis mengucapkan terima kasih kepada: (1) Bentara Budaya Yogyakarta yang telah memberi dana penelitian, (2) Program Pascasarjana ISI Yogyakarta, dan (3) Dr. M. Agus Burhan sebagai pembimbing penelitian ini.

\section{Kepustakaan}

Burhan, M. Agus. 2008. Perkembangan Seni Lukis Mooi Indië sampai Persagi di Batavia, 1900-1942. Jakarta: Penerbit Galeri Nasional Indonesia dan Departemen Kebudayaan dan Pariwisata Republik Indonesia. . 2003. "Seni Rupa Modern Indonesia: Tinjauan Sosiohistoris" dalam Aspek-Aspek Seni Visual Indonesia: Politik dan Gender. Yogyakarta: Yayasan Seni Cemeti.

Bustam, Mia. 2006. Aku dan Sudjojono. Jakarta: Pustaka Utan Kayu.

Canaday, John. 1962. Mainstreams of Modern Art. New York: Simon And Schuster.

Feldman, Edmund Burke. 1967. Art as Image and Idea. New Jersey: Prentice Hall, Inc.

Kartodirdjo, Sartono. 1987. Perkembangan Peradaban Priyayi. Yogyakarta: Gadjah Mada University Press.

Panofsky, Erwin. 1955. Meaning in the Visual Arts. Chicago: The University of Chicago Press.

Siregar, Aminudin Th. 2010. Sang Ahli Gambar: Sketsa, Gambar, dan Pemikiran S. Sudjojono. Tangerang: S. Sudjojono Centre.

Soekiman, Djoko. 2011. Kebudayaan Indis dari 
Zaman Kompeni sampai Revolusi. Yogyakarta: Komunitas Bambu.

Toer, Pramoedya Ananta. 2010. Bumi Manusia. Cetakan ke-15. Jakarta: Lentera Dipantara.

\section{Tesis:}

Yulimarni. 2011. “Tabut Subarang Tahun 2010 dalam Tradisi Muharram Masyarakat Pariaman di Sumatera Barat" [Tesis] Program Pascasarjana ISI Yogyakarta.

\section{Makalah:}

Burhan, M. Agus. 2003. "Kesadaran Sejarah dalam Seni Rupa Kontemporer". Bahan Kuliah
Program “Night Club”, Yayasan Seni Cemeti.

\section{Majalah:}

Sumardjo, Trisno. 1949. "Sudjojono Bapak Seni Lukis Indonesia Baru” dalam Majalah Mimbar Indonesia, No. 41, 8 Oktober 1949. Jakarta: Yayasan Dharma.

www.google.co.id/imgres? q=kursi+lenong+betawi +kuno di akses pada tanggal 10 Januari 2011. http://kolomkita.detik.com/baca/artikel/2/2027/ sejarah_hindia_belanda_di_belanda diakses pada tanggal 10 Januari 2012.

http://elyshashalies1.blogspot.com 